\title{
Az erdélyi könyvtörténetírás történetének vázlata
}

\section{Monok István}

\section{Outline of the History of Historical Bibliography in Transylva-} nia - In spite of being the most important area in the history of printing until the middle of the $18^{\text {th }}$ century, Transylvania can boast with a modest book publishing on a European scale. Thus the bibliographic recording of this publishing work, the book distribution, book-collecting, and book reading or the history of book art did not call for a separate scientific field to answer the questions that may arise, or separate institutions for the special researches. There are countries where the work on some subfields of book historiography (for example: letter history, history of print technology, book pathology, etc.) can use the books published in the given geographical area. This situation has advantages as well, because historical bibliography and library historiography could always remain interdisciplinary, its scholars being historians, or specialists of the history of literature, art, culture, or regional history.

The author surveys the results of the Hungarian, Saxon and Romanian historical bibliography in Transylvania on a bibliographic level, and evaluates certain historiographic tendencies. He also deals with the history of the research of certain group of resources and to historical bibliographic studies written during the process of bibliographical work. The common cataloguing, made possible by the spread of electronic equipment, opened new possibilities in the virtual unification of holdings. This will surely call into being new trends in library-and reading history studies. In the higher education students get acquainted with not only the technical details but all aspects of librarianship and the art of historical bibliography. This gives hope that historical bibliography has a future in Transylvania.

Erdély, annak ellenére, hogy a Kárpát-medencét tekintve a XVIII. század közepéig nyomdászattörténeti szempontból a legjelentősebb területi egység volt, ${ }^{2}$ európai léptékben szerény könyvkiadással dicsekedhet. İgy

${ }^{2}$ Összefoglalóan, a legfontosabb szakirodalom bibliográfiájával lásd: V. Ecsedy Judit: $A$ könyvnyomtatás Magyarországon a kézisajtó korában 1473-1800. Balassi Kiadó, Budapest, 
ennek a kiadói tevékenységnek a bibliográfiai számbavétele, a könyvkereskedelem, a könyvgyüjtés, illetve a könyvolvasás vagy a könyvművészet története nem igényelte, hogy a felvetődő kérdések megválaszolására önálló tudományos szakterület alakuljon ki, vagy a speciális kutatásokra elkülönült intézmények jöjjenek létre. Vannak országok, ahol a könyvtörténetírás egyes részterületeinek ( $\mathrm{pl}$. a betütörténet, a nyomdászati technika története, a könyvpatológia stb.) müvelése élethosszig tartóan táplálkozik az illető földrajzi terület könyvterméséből. Ennek az erdélyi helyzetnek vannak elönyei is, hiszen a könyv- és a könyvtártörténet-írás mindig interdiszciplináris tudott maradni, mert müvelői történészek vagy az irodalom-, a müvészet-, a művelődés-, vagy egyszerüen a helytörténet szakértői voltak.

A könyvtörténetírás Erdélyben is a historia litteralia müvelésének keretén belül alakult ki, és a saját munkásság számbavételével kezdődött. Szathmárnémeti Mihály autobibliográfiája prédikációs kötete latin (Kolozsvár, 1677) és magyar (Kolozsvár, 1686) kiadásának függelékében is szerepel. ${ }^{3}$ A XVIII. században azonban már - az európai mintákat, és David Czvittinger példáját ${ }^{4}$ követve - komoly és módszeres bibliográfiai tevékenység indult el. Már a Chronicon Fuchsio-Lupino-Oltardinum szerzöi ${ }^{5}$ is számba vették az Erdélyben aktív írói tevékenységet folytató kortársaikat, illetve kiadványaikat, és XVIII. századi követőik is számos - esetenként csak az ő említésükből ismert - erdélyi müröl, illetve kiadásról emlékeznek meg (Georg Soterius, Josef Teutsch, Georg Haner). Persze ezeknek a szerzőknek a célja nem az Erdélyben megjelent kiadványok bibliográfiai leírása volt, hanem az előd és a kortárs irodalom- és tudománymüvelö neves emberek életének és tevékenységének bemutatása, emlékezetük fenntartása. Csak ilyen értelemben tekinthető Benkő József Transilvaniája $(1778)^{6}$ is tárgyunkhoz tartozónak. Nem mehetünk el említés nélkül azon jelenség mellett, hogy a XVIII. századból ismertek a legnagyobb másolatgyüjtemények. A történészek - gondoljunk akár csak az említett nevekre - számos

1999.

${ }^{3}$ Dominica Catechetica (RMK II. 1402); Dominicalis Praedicatiok Toldalékai (RMK I. 1353); vö. Holl Béla: $A$ historia litteralia magyarországi története. = Holl Béla: Laus librorum. Válogatott tanulmányok. Szerk. Monok István, Zvara Edina. Bp., 2000, ME'TEM (ME'TEM Könyvek 26.) (a továbbiakban: Holl 2000) 94.

${ }^{4}$ Specimen Hungariae Litteratae... Francofurti et Lipsiae, 1711 (RMK III. 4767).

${ }^{5}$ Chronicon Fuchsio-Lupino-Oltardinum. Hrsg. von Joseph Trausch. Bd. 1-2. Kronstadt, $1847-1848$.

'Bécs, 1777-78 (majd 1788 és 1824). 
hazai, de főként másutt megjelent kiadványt másoltak vagy másoltattak le azért, mert nem volt elérhető példányuk. Ezzel a tevékenységükkel egyrészt - ma úgy mondanánk - hungarikumkutatást folytattak, másrészt, számos esetben, ismertté tettek olyan nyomtatványokat, amelyekböl ma egyetlen példány sem vehető kézbe.?

Két XVIII. századi tudósunkat azonban nagyobb joggal nevezhetjük akár bibliográfusnak is: Kénosi Tözsér Jánost, illetve Bod Pétert. Kénosi Tőzsér az erdélyi unitárius nyomdászokról, nyomdákról, illetve kiadványokról összeállított jegyzékét egyháztörténeti munkájával olvasztotta össze a munkát folytató Uzoni Fosztó István. A retrospektív magyar nemzeti bibliográfia összeállítói még napjainkban is haszonnal forgatják ezt a késve kiadott kéziratot. ${ }^{8}$ Bod Péter pedig a közismert Magyar Athenas (1766) mellett több müvében (a Biblia története, a református egyház története) is számba vette elődei munkásságát. A Magyar Athenas összeállításakor az egyes mủvek kézbevétele mellett bibliográfiai kutatást is folytatott azért, hogy az általa látott kiadványok sorát kiegészíthesse az egyes szerzők által megjelentetett más múvekkel. ${ }^{9}$

A XVIII. század folyamán, illetve az azt követö századfordulón Erdély három nagy nemzeti közössége külön-külön megalapitotta azokat a központi gyüjteményeket, amelyeknek egyik célja a közösség írott kulturális örökségének összegyưjtése, feldolgozása és megőrzése, illetve áthagyományozása volt. ${ }^{10}$ A hozzá nem férhető dokumentumokról pedig legalább információkat kívántak beszerezni.

${ }^{7}$ Jó képet ad a másolatgyưjtemények fontosságáról: Kulcsár Péter: Inventarium de operibus litterariis ad res Hungaricas pertinentiis ab initiis usque ad annum 1700 - A magyar történeti irodalom lelöhelyjegyzéke a kezdetektôl 1700-ig. Balassi-OSZK, Bp., 2003.

${ }^{8}$ Kénosi Tözsér János: De typographiis et typographis Unitariorum in Transylvania - Bibliotheca scriptorum Transylvano-Unitariorum. Compiled by Ferenc Földesi. Ed. by István Monok. Scriptum, Szeged, 1991, (Adattár XVI-XVIIl. századi szellemi mozgalmaink történetéhez 32.).

${ }^{9}$ Felvethetö még az is, hogy a Magyar Athenast író Bod anyagát Bethlen Kata könyvtára katalógusának összeállításával tette módszeressé. Vö. Simon Melinda - Szabó Ágnes: Bethlen Kata könyvtárának rekonstrukciója. Deé Nagy Anikó tanulmányával. Scriptum, Szeged, 1997. (A Kárpát-medence kora újkori könyvtárai 2.); Eva Mârza: Catalogul bibliotecii lui Bethlen Kata = Emlékkönyv a Teleki Téka alapitásának 200. évfordulójára 1802-2002. Szerk: Deé Nagy Anikó, Sebestyén-Spielmann Mihály, Vakarcs Szilárd. Mentor Kiadó, Marosvásárhely, 2002. (a továbbiakban: TelekiTéka Eml. 2002) 401-422.

${ }^{10}$ Vö. Monok István: Az olvasott örökség - hagyomány és megújulás. = Kulturális örökség társadalmi képzelet. Szerk.: György Péter, Kiss Barbara, Monok István. OSZK, Akadémiai Kiadó, Bp.,2005. 83-92.; ugyanez rövidítve: Könyv, könyvtái; könyvtáros 14(2005) Nr. 1. 3-10. 
A balázsfalvi román iskola könyvtára mindig törekedett, a felállított nyomda termékein kívül is az erdélyi román kiadványok megszerzésére. ${ }^{11} \mathrm{~A}$ XIX. század első felében azután Vasile Pop, ${ }^{12}$ és Timotei Cipariu ${ }^{13}$ is könyvgyüjtői és bibliográfiai horizontjukban tartották ezt a gyüjteményt.

Samuel Brukenthal, amellett, hogy az erdélyi bibliofília kiemelkedő alakjává vált gyủjteményének gazdagíásával, ő maga, de főként tanácsadói tudatosan foglalkoztak a transylvanica anyag gazdagításával. ${ }^{14} \mathrm{Azzal}$, hogy 1803-ban ez a könyvtár közösségi használatúvá vált, bővült annak a lehetősége, hogy az erdélyi vonatkozású anyag hiányai ismertté váljanak, és pótlásuk tudatos legyen. ${ }^{15}$

A központi gyüjtemények - könyvtár, levéltár, múzeum - kialakulása, a nemzetállamiság és a kulturális öntudat erősödése egyidejủ és általános jelenség Európában. ${ }^{16} \mathrm{~A}$ marosvásárhelyi Teleki Téka történetének minden korszakában jelen volt a gondolat, hogy a magyar nyomtatott emlékeket, illetve a magyar vonatkozású irodalmat összegyủjtse, de nyilvánossá válásával, a református kollégiumi gyủjteménnyel való együttes használat lehetőségével, önmagában is inspirálója volt a hiányok felfedésére, azok pótlására való törekvésnek. Ráadásul ez olyan korszakban történt, amikor az anyanyelvvel, így a nyelvemlékekkel való tudatos foglalkozás sokaknak kiemelt

"Jakó Zsigmond: A balázsfalvi nyomda kezdetei. = Jakó Zsigmond: Irás, könyv, értelmiség. Tanulmányok Erdély történelméhez. Kriterion, Bukarest, 1976. (a továbbiakban: Jakó 1976) 252-256.; Iacob Mârza: Das Schulzentrum Blasendorf, der Kern einer rumänischen Bibliothek in der Aufklärung. = Les bibliothèques centrales et la construction des identités collectives. Ed. par Frédéric Barbier, István Monok. Universitätsverlag, Leipzig, 2005. (L'Europe en résaux. Contributions à l'histoire de la culture écrite 1850-1918. - Vernetztes Europa. Beiträge zur Kulturgeschichte des Buchwesens 1650-1918. Bd. III.) (a továbbiakban: Barbier-Monok 2005). 155-162.

${ }^{12}$ Vö. Vasile Popp: Disertație despre tipografile româneşti in Transilvania şi invecinatele țări de la începutul lor până la vremile noastre. Sibiu, 1838. Ed. Eva Mârza, Jacob Mârza. Editura Dacia, Cluj Napoca, 1995. - bibliográfiával.

${ }^{13}$ Jakó Zsigmond: A Cipariu-könyvtár kialakulása és története. = Jakó 1976. 257-283.

${ }^{14}$ Göllner Carl: Samuel von Brukenthal. Sein Leben und Wert im Wort und Bild. Kriterion, Bukarest,1977; Kelecsényi Gábor: Múltunk neves könyvgyüjtöi. Gondolat, Bp., 1988. 147156.

15 Verók Attila: Die Gründung der Bibliothek Bruckenthal und ihr Einfluss auf das Geschichtsbewusstsein der Siebenbürger Sachsen. In: Barbier-Monok 2005. 125-132.

${ }^{16}$ Vö. Frédéric Barbier: Une histoire des „Bibliothèque centrales”. In: Barbier-Monok 2005. $9-32$. 
tudományos célja volt. ${ }^{17}$ Gondoljunk csak az Erdélyi Nyelvmủvelő Társaság ${ }^{18}$ vagy - Marosvásárhelyről lévén szó - Koncz József tevékenységére. ${ }^{19}$

A XIX. század második felében az oktatási, a tudományos és a kulturális intézményrendszer számos változáson esett át, jellemzően megerösödött. Elkezdődött a könyvtárak és nyomdák történelmi szempontú számbavétele is. ${ }^{20} \mathrm{Az}$ Erdélyi Múzeum-Egylet megalakulása, a gyüjtemény együttes gyarapítása a könyvtörténeti kutatásokat is fellendítette. Az Egylet elsö könyvtárosa Szabó Károly lett, aki ekkor már ismert volt „címmásolat”gyüjteményéröl. A Régi magyar könyvtár máig nélkülözhetetlen kötetei ekkor születtek, és ezzel a modern magyar retrospektív nemzeti bibliográfia. ${ }^{21}$ A Magyar Könyvszemle megalakulása (1876) mérföldkőnek tekinthető a könyvtörténeti kutatások történetében, ${ }^{22}$ hiszen Európában is az egyik első, erre a tudományterületre szakosodott folyóirat volt. György Aladár $\mathrm{Ma}$ gyarország magán-és közkönyvtárai címủ munkája, amely kiindulópontja a könyvtártörténeti kutatásoknak, 1886-ban jelent meg. A XX. század elején azután megjelentek a régi román nyomtatványok román bibliográfiai kötetei is: Bibliografia românească veche (1508-1830).

Könyv-, és könyvtártörténeti szempontból tehát a Millenium nagyszabású hely- és intézménytörténeti sorozatai és a történelmünk kiemelkedő személyiségeit bemutató monográfiák, jól előkészítettnek voltak mondhatóak, így a könyvtár, a könyvgyüjtés története nem hiányzik egyikükből sem. ${ }^{23}$ Még az első világháború előtt útjára indult a Könyvtári Minerva, amelyben az egyes könyvtárak történetének legfontosabb adatai is szerepel-

${ }^{17}$ Vö. Teleki Téka Eml. 2002.

${ }^{18}$ Vö. Bartha János (et alii): Az Erdélyi Magyar Nyelvmívelö Társaság kétszáz éve 1793-1993. EME, Kolozsvár, 1994, (Erdélyi Tudományos Füzetek 218.).

${ }^{19}$ Lásd Markó László címszavát az Új magyar irodalmi lexikonban (Fószerk.: Péter László. Akadémiai Kiadó, Bp., 2000. 1179.) és ennek bibliográfiai tételeit.

${ }^{20}$ Összefoglalóan: Holl 2000. 110-115.

${ }^{21}$ Szabó Károly: Régi magyar könyvtár I. (RMK I.). Az 1531-tól 1711-ig megjelent magyar nyelvü hazai nyomtatványok könyvészeti kézikönyve. Bp., 1879.; Szabó Károly: Régi magyar könyvtár II. (RMK II.) Az 1473-tól 1711-ig megjelent nem magyar nyelvü hazai nyomtatványok könyvészeti kézikönyve. Bp., 1885; Vö. Holl 2000. 116-118., illetve e kötetben Újvári Mária tanulmányával.

${ }^{22}$ Lásd a 100. évfolyamban megjelent köszöntéseket (1-2.; 131-132.)

${ }^{23}$ A kiadványok bibliográfiáját lásd a történeti és az irodalomtörténeti bibliográfiák köteteiben. Kifejezetten könyvtörténeti bibliográfia: Szelle Béla: Bibliográfia. = A könyv és könyvtár a magyar társadalom életében 1849-ig. Szerk.: Kovács Máté. Gondolat Kiadó, Bp., 1963. (Nemzeti Könyvtár) 653-728.; Neményi László: A magyar könyvtörténetírás irodalma. Ajánló bibliográfia. Székesfehérvár, 1976. 
tek. A historia litteralia történésze, Holl Béla a XX. század első évtizedeit az „adalék irodalom” évtizedeinek nevezi. ${ }^{24}$ Így igaz ez Erdélyt tekintve is. A Magyar Könyvszemle, az Erdélyi Múzeum és más fontos folyóiratok hasábjain, a XIX. század végén megjelent alapvető könyvészeti kézikönyvek és monográfiák bibliográfiai kiegészítésére számos közlemény született. Iványi Béla Könyvek, könyvnyomdák, könyvtárak Magyarországon címủ közleménysorozata a Magyar Könyvszemlében (1932-1936) sok erdélyi adatot is közölt, de kutatásai Erdélyben kirándulásjellegủek voltak. ${ }^{25}$ Herepei János könyvészeti tanulmányai azonban már új irányt mutattak, túlnóttek az egyszerü adatközlésen. Fontos megfigyeléseket közölt az egyes nyomdák betűkészletéről, díszítő elemeiröl, összekapcsolta a levéltárak gazdasági jellegü adatait a könyvekböl vagy éppen a kötésröl vett adalékokkal. Az 1942-ben megjelent 143. Erdélyi Tudományos Füzetek szemléletében határozottan modernnek mondható. ${ }^{26}$

Az európai könyvtörténeti kutatás ez időben fedezte fel magának a hagyatéki összeírást. ${ }^{27} \mathrm{Az}$ Annales iskola által indított a "mindennapok történetének" megírását előtérbe helyező könyvsorozatok bőven merítettek ebből a forrástípusból. Erdélyben, Magyarország számára is programot adó tanulmány jelent meg 1958-ban: Jakó Zsigmond a Kelemen-emlékkönyvben közzétette a kora újkori polgárság anyagi kultúrájára vonatkozó írását. ${ }^{28} \mathrm{~A}$ magyarországi történetírás csak késve reagált erre, de Erdélyben, nem utolsó sorban neki köszönhetően szorgos könyv- és könyvtörténeti forrásfeltárás vette kezdetét. A ma is hozzáférhető könyvanyag kéziratos bejegyzéseinek kutatása, a hagyatéki összeírásokban található könyvjegyzékek számbavétele az erdélyi könyvtörténetkutatás jelentős mozzanata volt. Ez utóbbiakat ő még nem választotta el - nagyon helyesen - az egyéb tárgyak összeírásától. 'Több szempontból ő tekinthető a sajnálatosan kevés kötéstörténeti feltárás inspirálójának is. 1976-ban megjelent tanulmánykö-

${ }^{24}$ Holl 2000. 119-122.

${ }^{25}$ Iványi munkásságának, adatgyủjtésének összefoglalása: A magyar könyvkultúra múltjából. Iványi Béla cikkei és gyüjtése. Sajtó alá rend., függelék: Herner János, Monok István. JATE, Szeged, 1983 (Adattár XVI-XVIII. századi szellemi mozgalmaink történetéhez 11.).

${ }^{26}$ Herepei János: Könyvészeti tanulmányok. EME, Kolozsvár, 1942 (Erdélyi Tudományos Füzetek 143).

${ }^{27}$ Lucien Febvre: Ce qu'on peut trouver dans une série d'inventaires mobiliers. Annales d'histoire sociale, 1941. 41-54.

${ }^{28}$ Jakó Zsigmond: Az otthon és müvészete a XVI-XVII. századi Kolozsváron = Kelemen Lajos Emlékkönyv. Bukarest-Kolozsvár, 1957. (A Bolyai Tudományegyetem Kiadványai I. Tanulmányok) 361-393. 
tete, az Írás, könyv, értelmiség, jó példája annak, hogy milyen elönyei vannak az interdiszciplináris szemléletnek, a különféle levél- és könyvtári forrásanyag együttes kezelésének.

Összehasonlításul állítsuk ide Gustav Gündisch alakját, aki az erdélyi szász lutheránus értelmiség olvasmányait a tulajdonosi bejegyzések alapján rekonstruált könyvtárakkal jellemezte. ${ }^{29}$ Nem tudunk arról, hogy ő maga külön szerette volna a hagyatéki iratokban szereplö jegyzékeket is feldolgozni, jóllehet Nagyszebenben valamennyi kötet járt az ő vagy felesége kezében. Ez a forráskör tanulmányaiban ugyanakkor néma maradt.

Jakó Zsigmond tanítványainak több generációja folytatta és folytatja ma is a munkát. Dankanits Ádám könyve a XVI. századi erdélyi olvasmányokról forrásbázisában nagyon szük maradt, szemléletében azonban modern, a francia szakirodalom ismeretét mutató. ${ }^{30} \mathrm{~A}$ források nagyobb szabású feltárása azonban a történeti kutatás ellehetetlenülése miatt csak később kezdődhetett el, és az erdélyi eredmények nagyrészt Magyarországon jelentek meg. Keserủ Bálint 1965-ben alapított Adattár XVI-XVIII. századi szellemi mozgalmaink történetéhez sorozatát Herepei és Jakó inspirálták. A sorozat ma 46 kötetet számlál. A könyv- és könyvtártörténeti kötetek erdélyi (és partiumi) munkatársai szinte valamennyien Jakó-tanítványok: Tonk Sándor, Sipos Gábor, Kovács András, Kiss Gyöngy, Jakó Klára, Deé Nagy Anikó, Muckenhaupt Erzsébet, Bura László. A szegedi Adattár sorozat mellett indult Könyvtártörténeti Füzetek bibliográfiai sorozat, ${ }^{31}$ csakúgy, mint a nagyobb tanulmányokat közlö Olvasmánytörténeti Dolgozatok ${ }^{32} \mathrm{~s}$ a Kárpát-medence kora újkori könyvtárai ${ }^{33}$ több erdélyi könyvtár történetének kismonográfia-szerü feldolgozását közölte:

29 Tanulmányai összegyüjtve is megjelentek a Schriften zur Landeskunde Siebenbürgens sorozat 14. köteteként: Aus Geschichte und Kultur der siebenbürger Sachsen. Ausgewählte Aufsätze und Berichte von Gustav Gündisch. Böhlau, Köln-Wien, 1987.

30 Dankanits Ádám: XVI. századi olvasmányok. Kriterion, Bukarest, 1974.

${ }^{31}$ 1981-tól 11. kötet, sorozatszerkesztő: Monok István.

32 Erdélyre vonatkozó kötetei: 1. kötet: Sipos Gábor: A kolozsvári Református Kollégium könyvtára a XVII. században. Scriptum, Szeged, 1991.; 7. kötet: Selecká-Mârza, Éva: A Középkori Löcsei Könyvtár. Scriptum, Szeged, 1997.

${ }^{33}$ A sorozatban erdélyi vonatkozásúak a következő kötetek: Bethlen Kata könyvtára (lásd a 8. jegyzetet); Emődi András: A Nagyváradi Székeskáptalan könyvtára a XVIII. században. Szerk.: Monok István. OSZK-Scriptum Rt., Budapest-Szeged, 2002. (a sorozat 5. kötete); Viskolcz Noémi: Johann Heinrich Bisterfeld (1605-1655) bibliográfia. A Bisterfeld-könyvtár. OSZK-Scriptum, Budapest-Szeged, 2003. (a sorozat 6. kötete) 


\section{EME}

Adattár XVI-XVIII. századi szellemi mozgalmaink történetéhez (Sorozatszerk: Keserü Bálint).

14. Partiumi könyvesházak 1623-1730. (Sárospatak, Debrecen, Szatmár, Nagybánya, Zilah). Sajtó alá rend. Fekete Csaba, Kulcsár György (= Bura László), Monok István, Varga András. A kötetet és a mutatókat összeáll. Monok István, Varga András. MTAK, JATE, Bp.-Szeged, 1988.

16/1. Erdélyi könyvesházak I. Jakó Klára: Az elsö kolozsvári egyetemi könyvtár története és állományának rekonstrukciója (1579-1604). Szerk. Monok István. Scriptum, Szeged, 1991.

16/2. Erdélyi könyvesházak II. Kolozsvár, Marosvásárhely, Nagyenyed, Szászváros, Székelyudvarhely. Jakó Zsigmond anyaggyüjtésének felhasználásával sajtó alá rend. Monok István, Németh Noémi, Tonk Sándor. Mutató: Farkas Gábor, Varga András. Szerk. Monok István. Scriptum, Szeged, 1991.

16/3. Erdélyi könyvesházak III. 1563-1757. A Bethlen-család és környezete. Az Apafi-család és környezete. A Teleki-család és környezete. Vegyes források. Sajtó alá rend. Monok István, Németh Noémi, Varga András. Szerk. Monok István. Scriptum, Szeged, 1994 [1995].

16/4/1-2. Erdélyi könyvesházak IV/1-2. Bibliotheken in Siebenbürgen IV/1-2. Lesestoffe der siebenbürger Sachsen 1575-1750. Bistritz, Hermannstadt, Kronstadt, Schäßburg, Kleinere Orte. Hrsg. von István Monok, Péter Ötvös, Attila Verók. Scriptum, Bp., 2004.

16/5. Erdélyi könyvesházak $V$. (előkészületben)

32. Kénosi Tözsér János: De typographiis et typographis Unitariorum in Transylvania. - Bibliotheca scriptorum Transylvano-Unitariorum. Compiled by Ferenc Földesi. Ed. by István Monok. Scriptum, Szeged, 1991.

Külön kell beszélnünk a régi könyvállományok katalógusairól, amelyek elsőrendủ könyvtörténeti források, különösen akkor, ha a kéziratos possessorbejegyzéseket és egyéb tulajdonjegyeket is közlik bennük.

Az ösnyomtatványok katalógusainak sorában a gyulafehárvári Batthyanaeum (Catalogus incunabulorum Bibliothecae Batthyanyanae. Conscriptus Petro Kulcsár. Szeged, 1965.), a nagyszebeni Brukenthal Múzeum (Veturia Jugăreanu: Catalogul colecției de incunabule. Muzeul Brukenthal. Sibiu, 1969.; a szerző erről a gyüjteményröl korábban önálló kötetet adott ki: Veturia Jugăreanu: Crîmpeie de cultură din secolul al XV-lea oglindite în colecția de incunabule a Bibliotecii Brukenthal din Sibiu. Muzeul Brukenthal, Sibiu, 1956. »Studii și comunicări 7.«), a marosvásárhelyi Teleki-Bolyai 
könyvtár (Fikk László - Balázs Lajos: Catalogus incunabulorum Bibliothecae Teleki-Bolyai. - Catalogul incunabulelor din Biblioteca Teleki-Bolyai. Tîrgu Mureş, 1971.) a kolozsvári Egyetemi Könyvtár (Elena Mosora - Doina Hanga: Catalogul incunabulelor. Biblioteca Centrală Universitară ClujNapoca. Editura Dacia, Cluj-Napoca, 1979.) említhetö meg. A Bukarestben levő Román Nemzeti Könyvtár több tekintetben erdélyinek tekinthető. A tulajdonosi bejegyzések igazolják ugyanis azt az egyébként közismert tényt, hogy leginkább az Erdélyből elhordott könyvanyag képezi a reprezentatív bukaresti könyvtárak állományának nagy részét. Az aradi, csíksomlyói és eperjesi (!) ferencesek könyvei mellett elöfordul a Batthyanaeumból oda került két kötet is, de számos más erdélyi bejegyzés is olvasható a kötetek leírásában (Elena-Maria Schatz: Catalogul colecției de incunabule. Biblioteca Națională a României, Bucureşti, 1995.).

Az erdélyi szász könyvtörténeti kutatásnak inkább nagy múltja, reméljük jövője, semmint jelene van. Átfogó jellegü munkák persze jelennek meg (lásd például: Hans Meschendörfer: Das Verlagswesen der siebenbürgen Sachsen. Ein Überblick. Verlag des Südostdeutschen Kulturwerks, München, 1979., Veröffentlichungen des Südostdeutschen Kulturwerks. Reihe B.: Wissenschaftliche Arbeiten. Bd. 36.), de a forráskutatáson nyugvó könyvtörténeti monográfiákat nem találjuk. A Vereins für siebenbürgische Landeskunde folyóiratai és könyvsorozatai a múlt századtól kezdve a mai németországi és ausztriai kiadványokig (historiográfiai áttekintésként lásd: Wege Landeskundlicher Forschung. 25 Jahre Arbeitskreis für Siebenbürgische Landeskunde 1962-1987. Red. von Konrad G. Gündisch. Böhlau, Köln-Wien, 1988. (Siebenbürgisches Archiv. Bd. 21.) számos fontos könyvtörténeti tanulmányt közöltek. Gustav Gündischnek, aki a legutóbbi évtizedekben talán a legtöbb figyelmet szentelte a könyv- és olvasmánytörténeti kutatásoknak, már nem volt ideje kiterjeszteni tevékenységét a levéltári dokumentumok összegyüjtésére. Tanulmányai - amint említettü ${ }^{34}$ - összegyüjtve is megjelentek. Legújabban Christian Rothertől jelent meg egy bibliográfiákban is gazdag összefoglalás: Siebenbürgen und der Buchdruck im 16. Jahrhundert, mit einer Bibliographie „Siebenbürgen und der Buchdruck". Harrassowitz, Wiesbaden, 2002. (Buchwissenschaftliche Beiträge aus dem Deutschen Bucharchiv München, 71.). Ha azonban azokat a könyveket akarjuk kézbe venni, amelyeket e tanulmányok említenek, Romániában kell keresnünk azokat. Ezért is fontosak a kiállítások (vö. például: Transylvanica. Ausstellung

${ }^{34}$ Lásd a 28. jegyzetet. 
seltener Bücher des XV. bis XIX. Jahrhunderts. 27. September bis 31. Oktober 1991. Katalog von Hans Meschendörfer. München, 1991 „Ausstellungskataloge der Bayerische Staatsbibliothek. 57.«) és az ott maradt gyüjtemények katalógusai. A nagyszebeni könyvtárak közül a legjelentősebb a Brukenthal Múzeum régi gyüjteménye: Doina Nägler: Catalogul transilvanicelor. Biblioteca Muzeului Brukenthal. I. (Sec. XVI-XVII.), II. (Sec. XVIII.) Sibiu, 1974,1982 . A Brukenthal Múzeum nem transylvanica anyagának katalógusa persze olvasmánytörténeti szempontból legalább ilyen fontos lenne, de erre, látva a mostani állapotokat, még várnunk kell.

Nagyszeben másik, jelentősebb régi könyvállománnyal rendelkező gyüjteménye a román nemzeti kulturális mozgalom, az Astra könyvtára (Mircea Avram: Calendarele Sibiene în limba germană (sec. XVI-XX.). Editura Bibliotecii Astra, Sibiu, 1979.) A szerző az erdélyi, főként a nagyszebeni nyomdászat történetének kutatója, elsősorban a XVIII-XIX. századi kiadványok elemzésével foglalkozik (Vö. Elena Dunăreanu-Mircea Avram: Presa sibiană în limba germană (1778-1970). Biblioteca Astra, Sibiu, 1971.). Az Astra könyvtárának állománykatalógusai közül az utóbbi időben a XVIII. századi európai nyomtatványoké jelent meg: Lucian Cornea: Cartea străină veche in Bibliotheca "Astra” sec. XVIII. Catalog. Editura Bibliotecii Astra, Sibiu, 1982.

Fontos kiemelten utalni Gernot Nussbächer áldozatos és termékeny munkásságára. Ö Brassóban maradt, könyvtörténeti jellegű tanulmányai föként Johann Honterhez kötődnek. ${ }^{35}$ Részben neki köszönhető, hogy Brassóban a román és a szász fiatalok körében akadt utód, így elkezdődött a Fekete-templom könyvtárának feldolgozása.

A romániai kutatás természetesen nagy hangsúlyt helyez a román nyelvü kiadványok történetére, illetőleg a könyvnek a román társadalomban betöltött helyére. A Demény-házaspár tanulmányai összegyüjtve is megjelentek (Demény Lajos - Lidia A. Demény: Carte, tipar şi sociatate la români în secolul al XVI-lea. Editura Kriterion, Bucureşti, 1986.), de ezt követően is több önálló kötet is foglalkozik a XVI-XVIII. századi román kiadványokkal. Példaként a balázsfalvi kiadványok fametszeteit bemutató Cornel Tatai-Baltă könyvét (Gravorii în Lemn de la Blaj. 1750-1850. Editura Eventus, Blaj, 1995.), a szlovák Eva Selecká-Mârza, a gyulafehérvári

${ }^{35}$ Beträge zur Honterus-Forschung. 1966-1989. Aldus, Kronstadt, 2003.; 1989-2004. Aldus, Kronstadt, 2005. 
román nyomdászatról szóló monográfiáját (Eva Mârza: Din istoria tiparului românesc. Tipografia de la Alba Iulia 1577-1702. Editura Imago, Sibiu, 1998., és Sofia Ştirban víxjelkutatásait említhetjük (Din istoria hârtiei şi filigranului: tipografia românească a Bălgradului (sec. XVII.), Universitatea „1 Decembrie 1918”, Alba Iulia, 1999. (Biblioteca Universitatis Apulensis 3). A román bibliográfia számon tartott képviselöjének Timotei Cipariunak munkája (1855) elött készült el Vasile Popp nyomdászattörténete, amelyet a Mârza-házaspár adott ki 1995-ben (Vasile Popp: Disertație despre tipografille românești în Transilvania și învecinatele țări de la inceputul lor până la vremile noastre. Stibiu, 1838. Ed. Eva Mârza, Jacob Mârza. Editura Dacia, Cluj Napoca, 1995. . A Bibliografia românească veche (1508-1830) vol. I-IV. 1903-1944. kiegészítéseként, illetve a régi román, illetve a románokra vonatkozó kiadvánwok, a könyvek használatának vizsgálatát elősegítő leírási móddal több kötet is megjelent: Elena Mosora - Doina Hanga: Catalogul cărții vechi româneşti din colecțile Bibliotecii Centrale Universitare "Lucian Blaga” Clwj-Napoca. Editura Bibliotecii, Cluj-Napoca, 1991. A nagyváradi Gheorghe \$incai Megyei Könyvtár 129 könyvének részletes bemutatását találjuk a kövètkezö katalógusban: Constantin Mălinas: Catalog de carte românească veche. 1643-1830. Biblioteca Județeană „Gheorghe Şincai" Editura Mihail Eminescu, Oradea, 1993. (Bibliotheca bibliologica. Seria de restituiri "Festirta lente”. Cărți oprite de cenzura comunistă 1.). Nem csupán a román nyelwü kötetek szerepelnek a leírtak között, hanem a jelzett időhatáron belül kiædott román ortográfiák, nyelvtanok, valamint a románok eredetéről írott könyvek is. Folytatódott a XV-XVI. századi könyvek katalógusainak közreadása a 90-es évek második felében is (Rodica Maiorescu: Carte veche străină, sec. XVI. Catalog. Biblioteca Națională a României, București, 1996: Paula Vasil-Marinescu - Marta Cordea: Cartea veche străină în biblioteca județeană Satu Mare sec. XV-XVI. Catalog. Tipografia Someşul, Satu Mære, 1998; Tipărituri de Strasbourg în colecția de patrimoniu a Bibliotecii „A. D. Xenopol” Arad. Catalog secolele XV-XVIII. - Livres strasbourgeois dams le fonds patrimonial de la Bibliothèque „A. D. Xenopol" d'Arad. Catalogu XVe-XVIIle siècles. [Catalogue par Florin Didilescu] Editions Nigredo, Arad, 2003.), de a könyvtártörténet fontos forrásai, az egykori katalógusok közül is jelent meg példaszerủen egy: Ileana Dârja: Fondul Migazzi. Surse dociwmentare. I-IV. Biblioteca Națională a României. Filiala „Batthyaneum”, Alb Iulia, 1998-1999. 
Az erdélyi és partiumi magyar könyvtörténeti kutatás, köszönhetöen a bővülő lehetőségeknek - és annak, hogy a Jakó-tanítványoknak már lettek tanítványai, lelkes követői -, gyorsan számos területen kiváló kötetekkel örvendeztette meg az érdeklődő szakmai közönséget. Az EMKE könyvtári szakosztálya is áttekintette a régi könyvekkel kapcsolatos könyvtári teendőket. ${ }^{36}$ Újabb szakszerü katalógusok jelentek meg: Mihály SpielmannSebestyén - Lajos Balázs - Hedvig Ambrus - Ovidia Mesaroş: Catalogus librorum sedecimo saeculo impressorum Bibliothecae Teleki-Bolyai Novum Forum Siculorum, Vol. I-II, Biblioteca Județeană Mureș, Târgu Mureș, 2001. ${ }^{37}$ Szabó Henriette: A Dévai Ferences Rendház 1850 elötti könyvei. Katalógus. OSZK, Osiris (Nemzeti Téka), Bp., 2002.; A Kolozsvári Akadémiai Könyvtár Régi Magyar Könyvtárgyüjteményének katalógusa. - Catalogul colecțiilor Biblioteca Maghiară Veche a Bibliotecii Academiei Cluj-Napoca. Összeáll.: Kovács Mária, Kuszálik Eszter, Sántha Emese, Sipos Gábor, Szöke Imola. Szerk.: Sipos Gábor. Scientia Kiadó, BA Cluj-Napoca, Kolozsvár, 2004.; Emődi András: A Nagyváradi Római Katolikus Egyházmegyei Könyvtár régi állománya I. Szerk.: Monok István. Akadémiai Kiadó, Egyházmegyei Könyvtár, OSZK, Bp. - Nagyvárad, 2005. (A Kárpát-medence magyar könyvtárainak régi könyvei. Altbücherbestände ungarischer Bibliotheken im Karpatenbecken I). ${ }^{38}$

Emődi András a legjobb példákat követve nem csupán a mostani könyvállomány katalógusokat adja ki, de a könyvtár- ${ }^{39}$ és a nyomdászattörténeti ${ }^{40}$ összefüggésekre is ügyel. Személyében Bura László kiváló fiatal kollégára talált. ${ }^{41}$ Emődi számára a legjobb példákat Jakó Zsigmond, Sipos Gábor, Deé Nagy Anikó és Muckenhaupt Erzsébet szolgáltatták munkájához.

A csíksomlyói nyomda és a könyvtár történetének számos részletét feltáró tanulmány mellett Muckenhaupt Erzsébet külön kiadványban mu-

\footnotetext{
${ }^{36}$ Örökség és feladat. Tanulmányok romániai magyar könyvekröl, könyvtárakról. Szerk.: Kiss Jenö. EMKE, Sepsiszentgyörgy, 1995.

${ }^{37}$ Hamarosan megjelenik a XVII. századi állományt számba vevő kötet is.

${ }^{38}$ A sorozat következő kötetében a nagyváradi kapucinusok könyvtárát mutatja be Emődi András, illetve a nagyenyedi minoriták könyvanyagát Rácz Emese.

${ }^{39}$ Lásd a 32. jegyzetet.

${ }^{40}$ Emődi András: A Nagyváradi Szemináriumi Nyomda 1745-1804. Egyházmegyei Könyvtár, OSZK, Nagyvárad-Budapest, 2004.

41 Bura László egy tanulmánykötetben foglalta össze a lakóhelyének könyvtártörténetét: Könyvek és könyvtárak Szatmáron és Németiben. A XVII. századtól a XIX. század közepéig. Státus Kiadó, Csíkszereda, 2004.
} 
tatta be az ott örzött ritka kötéseket, ${ }^{1}$ magukat, az 1980-évek első felében megtalált kincseket, ${ }^{2}$ illetve kiállításon a nyomda és a könyvkötő mühely történetét. ${ }^{3}$

Deé Nagy Anikó életmüvének nagy része a Teleki Tékához kötődik. Modern monográfiában foglalta össze az alapítóra vonatkozó ismereteket, ${ }^{4}$ majd kiadta a könyvtárban található ex librisek leírását. ${ }^{5}$ Munkatársaival megszervezte a 200 éves ünnepségeket, külön konferencián tekintették át az erdélyi könyves kultúra történetét, ${ }^{6}$ és megjelenés előtt áll a nyomdászjelvényekről írt könyve.

Az elektronikai eszközök elterjedése a könyvtári munkában Erdélyben is azt eredményezte, hogy a közös katalogizálás révén új lehetőségek nyíltak az egykor együvé tartozott könyvállományok virtuális egyesítésére, és ez bizonnyal újabb könyvtár- és olvasmánytörténeti kutatási irányokat hív életre. A felsőoktatásban lehetőség van arra, hogy a könyvtárosságnak, a könyvtörténetírás mesterségének ne csak a technikai részét ismerjék meg az érdeklödők, és ez reményt ad ahhoz, hogy a könyvtörténeti kutatásoknak jövője van Erdélyben.

${ }^{1}$ XVI. századi német reneszánsz típusú szignált könyvkötések a csíksomlyói müemlékkönyvtárgyủjteményében. EME, Kolozsvár, 1993. (Erdélyi Tudományos Füzetek 216.)

2 A Csíksomlyói Ferences Könyvtár kincsei. Könyvleletek 1980-1985. Balassi Kiadó, Bp., 1999.

${ }^{3}$ A csiksomlyói ferences nyomda és könyvkötö mühely 1676-2001. Emlékkiállítás. Csíkszereda, 2001.

${ }^{4}$ A könyvtáralapitó Teleki Sámuel. EME, Kolozsvár, 1997.

${ }^{5}$ A Marosvásárhelyi Teleki-Bolyai Könyvtár ex librisei. Balassi, Polis, Bp. - Kolozsvár, 2001.; megjegyezzük, hogy ugyanebben az évben elindult a román nemzeti könyvtár állományában fellelhető ex librisek katalógusának kiadása is: Rodica Stamatopol: Ex libris în colecția Bibliotecii Naționale a României. Catalog. București, 2001. - számos magyar gyüjtỏ tulajdonjegyének dokumentálásával.

${ }^{6} \mathrm{Az}$ emlékkönyv megjelent (vö. 8. jegyzet), a második konferencia anyaga kiadás elött áll. 